\title{
A STUDY OF LOW BIRTH WEIGHT IN A PRIMARY HEALTH CENTRE OF CACHAR DISTRICT, ASSAM- A RECORD BASED STUDY
}

\author{
Debojit Chutia1, Hemen Sharma²
}

${ }^{1}$ Associate Professor, Department of Community Medicine, Silchar Medical College.

2Demonstrator, Silchar Medical College.

\section{ABSTRACT}

\section{BACKGROUND}

A baby's weight at birth is the key determinant for its survival and development. It reflects the health and nutritional status of the mother during reproductive period and particularly in pregnancy. The objective of this study is to know the proportion of low birth weight neonates and the effect of maternal age and parity on birth weight.

\section{MATERIALS AND METHODS}

A retrospective study was conducted, whereby data was obtained from the delivery records maintained at the Sonai primary health centre (PHC) from April 2016 to March 2017.

Statistical Analysis Used- Chi-square test.

\section{RESULTS}

The proportion of LBW neonates was found to be $11.08 \%$. Majority of the LBW neonates, i.e. $90.4 \%$ weigh between 1.5 and $2.5 \mathrm{~kg}$. Percentage of LBW neonates was found to be highest among women less than 20 years (13.5\%) of age and in multipara (26.8\%).

\section{CONCLUSION}

Emphasis has to be laid on universal and early registration of pregnant women, regular antenatal check-ups and nutrition education of rural mothers.

\section{KEYWORDS}

Proportion, Low Birth Weight, Primary Health Centre, Sonai.

HOW TO CITE THIS ARTICLE: Chutia D, Sharma H. A study of low birth weight in a primary health centre of Cachar district, Assam - a record based study. J. Evolution Med. Dent. Sci. 2017;6(82):5772-5774, DOI: 10.14260/jemds/2017/1252

\section{BACKGROUND}

A baby's weight at birth is the key determinant for its survival and development. It reflects the health and nutritional status of the mother during reproductive period and particularly in pregnancy. Low birth weight has been defined by the WHO, as weight at birth is less than 2500 gms (5.5 pounds). ${ }^{1}$ Globally, more than 20 million infants representing 15.5 percent of all births are born with low birth weight and 95.6 percent of them in developing countries. ${ }^{2}$ India alone accounts for 40 percent of low birth weight births in the developing world and more than half of those in Asia. ${ }^{2}$

LBW may result from preterm birth (before 37 weeks of gestation) or foetal growth retardation. Many socioeconomic factors such as mother's age and occupation, birth order, the family's income and many maternal conditions such as nutritional status, mother's educational and health status are related to LBW. ${ }^{3}$ Low birth weight is one of the most serious challenges in maternal and child health in developing countries. Its public health importance lies on the fact that it is closely associated with numerous adverse health outcomes such as mental retardation, high risk of perinatal

'Financial or Other Competing Interest': None.

Submission 18-08-2017, Peer Review 30-09-2017,

Acceptance 06-10-2017, Published 12-10-2017.

Corresponding Author:

Dr. Debojit Chutia,

Associate Professor

Department of Community Medicine,

Silchar Medical College and Hospital,

Silchar-788014.

E-mail:drdebojit@gmail.com

DOI: $10.14260 /$ jemds $/ 2017 / 1252$

\section{(c) $(1)(5)$}

and infant mortality as well as economic burden due to very high cost of special care and intensive care unit (ICU). ${ }^{4}$ It contributes to half of all perinatal and one-third of all infant deaths. The infant mortality rate is about 20 times higher for all low birth weight babies than other babies. Many of the low birth weight newborns become the victims of protein energy malnutrition (PEM) and infection. ${ }^{5}$

LBW has long been used as a sensitive public health indicator. Its prevalence in any country reflects its socioeconomic development. The major challenge in the field of public health is to identify the factors influencing low birth weight and to institute remedial measures. ${ }^{6}$ If the maternal risk factors are identified early and appropriate intervention measures are taken, proportion of LBW can be reduced. A good quality maternal and child health service would help in this aspect.

Not much studies are found related to LBW in rural health facilities. Therefore, the present study was undertaken to determine the prevalence of low birth weight in newborns in a primary health centre of Cachar, Assam.

\section{MATERIALS AND METHODS}

The present hospital-based retrospective study was conducted in the Sonai Primary Health Centre, Cachar, Assam. All the woman who were delivered from April 2016 to March 2017, i.e. over a period of 12 months were included in the study. A total of 2238 women were delivered during this period. Data were collected from delivery register maintained by the hospital. The delivery register gives information about maternal age, parity, child birth weight and sex of child. Subjects included were those having live births through normal, assisted or instrumental deliveries. The weights of 
the new-borns were measured without clothes on a digital weighing scale soon after the birth. Birth weight of less than $2500 \mathrm{gm}$ is considered as low birth weight baby. The mother's age was taken as per case sheet record. Data was analysed using SPSS version 20 statistical software. Chisquare test was applied as a test of significance.

\section{Ethical Consideration}

Ethical clearance was obtained from the Institutional Ethics Committee of Silchar Medical College prior to commencement of the study.

\section{Definitions}

\section{Birth Weight}

Weight of the new-born should be obtained immediately after birth and ideally it should be measured within the first hour of birth before significant postnatal weight loss occurs.

\section{Low Birth Weight}

Birth weight of a new-born baby who weighs $2.5 \mathrm{~kg}$ or less irrespective of gestational age.

\section{RESULTS}

A total of 2238 deliveries were conducted in the hospital over a period of 12 months. The total number of live births was 2174. Maternal age ranged between 18 and 37 years. The proportion of LBW neonates was found to be $11.08 \%$.

Table 1 shows the age distribution of pregnant women admitted to the PHC of Sonai, Cachar, Assam. The table shows that maximum number of pregnant women, i.e. $42.9 \%$ was between the age group of 25 and 29 years.

Table 2 shows the distribution of low birth weight babies in the last 12 months according to weight. Out of a total of 2174 live births, $241(11.08 \%)$ were low birth weight and maximum number of low birth weight babies (90.4\%) had birth weight between 1.5 and $2.5 \mathrm{~kg}$.

Table 3 shows the association of low birth weight with maternal age. The table shows that maximum number of low birth weight babies $(13.5 \%)$ was born to women in the age group of less than 20 years. The association however was not statistically significant.

Table 4 shows the association of parity with low birth weight showing the incidence of low birth weight to be maximum $(26.8 \%)$ in multipara, which was found to be statistically significant.

\begin{tabular}{|c|c|c|}
\hline Age Group & Number & Percentage (\%) \\
\hline$<20$ years & 82 & 3.7 \\
\hline $20-24$ & 805 & 36 \\
\hline $25-29$ & 961 & 42.9 \\
\hline$>30$ & 390 & 17.4 \\
\hline Total & $\mathbf{2 2 3 8}$ & $\mathbf{1 0 0}$ \\
\hline
\end{tabular}

Table 1. Distribution of Pregnant Women according to Age

\begin{tabular}{|c|c|c|}
\hline Body Weight (Kg) & Total & Percentage (\%) \\
\hline$<1$ & 6 & 2.4 \\
\hline $1-1.49$ & 17 & 7.05 \\
\hline $1.5-2.5$ & 218 & 90.4 \\
\hline Total & $\mathbf{2 4 1}$ & $\mathbf{1 0 0}$ \\
\hline $\begin{array}{c}\text { Table 2. Distribution of Low Birth Weight Baby in last 12 } \\
\text { Months }\end{array}$ \\
\hline
\end{tabular}

\begin{tabular}{|c|c|c|c|c|}
\hline $\begin{array}{c}\text { Age Group } \\
\text { (Years) }\end{array}$ & $\begin{array}{l}\text { No. of } \\
\text { LBW }\end{array}$ & $\begin{array}{c}\text { No. of Live } \\
\text { Births }\end{array}$ & (\%) & \multirow{6}{*}{$\mathrm{P}>0.05$} \\
\hline$<20$ years & 11 & 81 & 13.5 & \\
\hline $20-24$ & 88 & 773 & 11.3 & \\
\hline $25-29$ & 101 & 938 & 10.7 & \\
\hline$>30$ & 41 & 382 & 10.7 & \\
\hline Total & 241 & 2174 & 11.08 & \\
\hline
\end{tabular}

\begin{tabular}{|c|c|c|c|c|}
\hline Parity & $\begin{array}{l}\text { No. of } \\
\text { LBW }\end{array}$ & $\begin{array}{l}\text { No. of Live } \\
\text { Births }\end{array}$ & $\begin{array}{c}\text { Percentage } \\
(\%)\end{array}$ & \multirow{7}{*}{$\mathrm{P}<0.05$} \\
\hline Primi & 79 & 580 & 13.6 & \\
\hline 2nd Para & 79 & 754 & 10.4 & \\
\hline $3^{\text {rd }}$ Para & 52 & 590 & 11.3 & \\
\hline $4^{\text {th }}$ Para & 13 & 183 & 14.1 & \\
\hline Multipara & 18 & 67 & 26.8 & \\
\hline Total & 241 & 2174 & 11.08 & \\
\hline \multicolumn{5}{|c|}{ Table 4. Association of Parity with Low Birth Weight } \\
\hline
\end{tabular}

\section{DISCUSSION}

Birth weight is the single most important criterion for determining the neonatal and infant's survival. LBW is associated with high infant mortality, especially of deaths within the first month of life. Over the decades, several intervention programmes including Reproductive and Child Health and in recent years RMNCH + A (reproductive, maternal, new-born, child and adolescent health) have been launched all over India to improve the health status of mothers and children.

This study was carried out in a rural Primary Health Centre, Sonai, Cachar, Assam among 2238 number of delivered mothers to determine the prevalence and to assess some of the maternal factors associated with LBW.

In our study, proportion of LBW was found to be $11.08 \%$ which is low compared to that observed in other hospitalbased studies by Lateef $\mathrm{E}$ et $\mathrm{al}^{7}(29.65 \%)$ and Rajashree $\mathrm{K}$ et $\mathrm{al}^{8}$ (31.3\%). Joshi SM et $\mathrm{al}^{9}$ and Nayak RK et al ${ }^{10}$ found a low proportion of LBW $11.8 \%$ and $8.3 \%$ respectively. These variations could be more number of high risk deliveries in secondary and tertiary level hospitals and also better availability and utilisation of antenatal services in rural areas. In the present study maximum number of pregnant women, i.e. $42.9 \%$ were between the age group of 25 and 29 years, similar to a study done by Ade A et al, 11 which may be a factor of increased age at marriage, delaying the first pregnancy or maintaining birth interval. In this study, the proportion of LBW is high in women less than 20 years of age. Similar observations were also reported by Negi et $\mathrm{al}^{12}$ and Kamaladoss et al. ${ }^{13}$ In the present study, majority (90.4\%) of LBW babies were in the weight category of 1.5 to $2.5 \mathrm{~kg}$, Similar findings were also observed in the study conducted by Lateef et $\mathrm{al}^{7}$ and Nayak RK et al. ${ }^{10}$ In this study majority (26.8\%) of LBW was observed amongst multipara mothers and found statistically significant, which is quite similar to observation of Nirmalya Manna et al. ${ }^{14}$ On the contrary to this, a study done by Gosavi SV et al ${ }^{15}$ observed higher proportion of LBW in primiparous mothers.

\section{Limitation of Study}

Proper antenatal care plays a crucial role in the outcome of pregnancy. Since this is a hospital-based retrospective study, we could not obtain precise information regarding quality of antenatal care, iron folic acid intake and risk status of mother. 
Moreover, we could not obtain all socio-demographic data, which may have co-relation with low birth weight. As it is a hospital-based study from a single hospital, only those neonates born at the PHC were included.

\section{CONCLUSION}

In the present study, the proportion of low birth weight in Sonai PHC was $11.08 \%$, which is lower than the national average for rural areas. Some of the factors related with low birth weight are maternal age at delivery, parity and short birth interval. It is the need of the hour to strengthen the existing maternal health services at the basic level of community, i.e. at door steps of the beneficiaries. Therefore, our study recommends improvement in early registration of antenatal mothers, universal coverage of adequate and quality antenatal care, early detection of high risk pregnancy, maternal nutrition during pregnancy, avoiding close birth spacing and delayed child bearing in young females $<20$ years).

\section{ACKNOWLEDGEMENTS}

We are thankful to Dr. NG Surendra Singh, Sonai PHC, for the permission and helping in getting the data. We thank all GNM staffs and staffs of block programme management unit, who have extended their cooperation for the study.

\section{REFERENCES}

[1] World Health Organization, International statistical classification of diseases and related health problems tenth revision, World Health Organization, Geneva, 1992.

[2] UNICEF. United Nations children's fund and world health organization, low birth weight: country, regional and global estimates. New York: UNICEF 2004.

[3] Gebremedhin M, Ambaw F, Admassu E, et al. Maternal associated factors of low birth weight: a hospital based cross-sectional mixed study in Tigray, Northern Ethiopia. BMC Pregnancy Childbirth 2015;15:222.

[4] Agarwal N, Reddaiah VP. Factors affecting birth weight in a sub-urban community: a study in a secondary level hospital in Delhi. Health and Population-Perspectives and Issues 2005;28(4): 189-96.
[5] Park K. Park's text book of preventive and social medicine. 22nd edn. Banarasidas Bhanot Publication, Jabalpur, 2013:pp 496.

[6] Velankar DH. Maternal factors contributing to low birth weight babies in an urban slum community of Greater Mumbai. Bombay Hospital Journal 2009;51(1):26-35.

[7] Lateef E, Gupta P, Srivastava JP. The prevalence of low birth weight infants amongst hospital deliveries in Lucknow. Int J Community Med Public Health 2015;2(4):510-2.

[8] Rajashree K, Prashanth HL, Revathy R. Study on the factors associated with low birth weight among newborns delivered in a tertiary-care hospital, Shimoga, Karnataka. Int J Med Sci Public Health 2015;4(9):1287-90.

[9] Joshi SM, Likhar SK, Athavale AV, et al. Factors affecting birth weight: a study in a secondary level hospital in gas affected area of Bhopal. Natl J Community Med 2013;4(4):570-3.

[10] Nayak RK, Metgud CS, Mallapur MD, et al. Prevalence of low birth weight at primary health centre of north Karnataka. Int J Pharm Med \& Bio Sci 2013;2(1):1-4.

[11] Ade A, Brunda NK, Patil R. A retrospective study of birth weight and their risk factors among rural women. Int J Health Sci Res 2016;6(8):19-23.

[12] Negi KS, Kandpal SD, Kukreti M. Epidemiological factors affecting low birth weight. J K Sci 2006;8(1):31-4.

[13] Kamaladoss T, Abel R, Sampathkumar V. Epidemiological co-relates of low birth weight in rural Tamil Nadu. Indian J Pediatr 1992;59(3):299-304.

[14] Nirmalya M, Jhuma S, Baijayanti B, et al. Sociobiological determinants of low birth weight: a community based study from rural field practice area of medical college, Kolkata, West Bengal (India). IOSR Journal of Dental and Medical Sciences 2013;4(4):339.

[15] Gosavi SV, Koparkar AR. Predictors of low birth weight: a retrospective study from rural India. Int J Contemp Pediatr 2014;1(1):7-9. 